OPEN ACCESS

Edited by:

George Thomas Stilwell, University of Lisbon, Portugal

Reviewed by:

Patrizia Ana Bricarello,

Federal University of Santa

Catarina, Brazil

Jessica Quijada

Langston University, United States

*Correspondence:

Katarina Nenadović

katarinar@vet.bg.ac.rs

Specialty section:

This article was submitted to Animal Behavior and Welfare,

a section of the journal

Frontiers in Veterinary Science

Received: 10 March 2021

Accepted: 28 July 2021

Published: 31 August 2021

Citation:

Nenadović K, llić T, Jovanović $N$ Bugarski D and Vučinić M (2021) Welfare of Native Goat Breeds in Serbia-Emphasis on Parasitological Infections. Front. Vet. Sci. 8:678880.

doi: 10.3389/fvets.2021.678880

\section{Welfare of Native Goat Breeds in Serbia-Emphasis on Parasitological Infections}

\author{
Katarina Nenadović ${ }^{1 *}$, Tamara $l i c^{2}$, Nemanja Jovanović ${ }^{2}$, Dejan Bugarski ${ }^{3}$ and \\ Marijana Vučinić ${ }^{1}$
}

${ }^{1}$ Department of Animal Hygiene, Faculty of Veterinary Medicine, University of Belgrade, Belgrade, Serbia, ${ }^{2}$ Department of Parasitology, Faculty of Veterinary Medicine, University of Belgrade, Belgrade, Serbia, ${ }^{3}$ Scientific Veterinary Institute "Novi Sad", Belgrade, Serbia

Native goat breeds in Serbia has been recognized as an important element of regional agrobiodiversity and play an important role in the safeguarding of cultural and traditional heritage. The aim of this study was to identify the main welfare issues likely to be encountered in extensive goat farming systems with an emphasis on parasitological infections. The study was conducted during the winter season on four small farms of native Balkan and Serbian white goats. For welfare assessment, animal-based indicators from AWIN protocol for goats were used. All fecal samples for parasites were qualitatively and quantitatively examined. The main welfare issues identified were poor hair coat condition (62.79\%), dirty and light soiling hindquarters (31.40\%), thin body condition score (26.74\%), abscesses (19.78\%), and udder asymmetry (18.60\%). In addition, an important and prevalent welfare problem identified across all farms was parasite infection and weak significant $(p<0.001)$ correlation between certain parasites (Strongylidae, Moniezia spp., Buxtonella sulcate, and Protostrongylidae) and welfare indicators such as poor hair coat condition and nasal discharge. The results of this study provided the first overview and valuable insight into the impact of extensive systems on the welfare of native goats in the Balcan region.

Keywords: animal welfare, animal-based indicators, extensive systems, goats, parasites

\section{INTRODUCTION}

In Serbia, at present, there is very little information as to the welfare of goats. Before the Second World War, in the Republic of Serbia, goat breeding had a significant place and was mostly represented as an extensive production, in the hilly, mountainous area (1). With the adoption of the Law on the Prohibition of Goat Breeding in 1954 (2), goat farming has become forbidden, which negatively influenced the overall size of the goat population in Serbia, as well as the presence of native goat breeds (1). The goat farming sector in Serbia has been rapidly developing during the last decades. Currently, in Serbia, there are 180,000 breeding goats (3). According to the Institute for Animal Husbandry's annual report, only 13 smallholder farms with a total of 429 native goat breeds are registered in Serbia today.

Native goat breeds in Serbia represent valuable and irreplaceable genetic resources and play an important role in the safeguarding of cultural and traditional heritage (1). There are two local goat breeds currently raised in Central and Eastern Serbia, Balkan goat and Serbian white goat, with 
Balkan goat being the native breed and Serbian white basically being improved Balkan by crossing with Saanen bucks aimed at improving milk yield (1). Both of these breeds are very endurable that is easily adapted to modest conditions of care, housing, and nutrition, usually raised extensively in hilly, mountainous regions (1) and only during the winter season when there is provision of supplementary feeds at home in addition to grazing, then the production system is considered as semi-extensive.

Both breeds are used for combined production of both milk and meat, but for Balkan goat, the meat is the most important product (4), while Serbian white goat has higher milk production (1).

Extensive management systems allow animals to behave in a more natural way and express natural behaviors such as grazing, exploration, or exercise, which may be beneficial for their health $(5,6)$. These characteristics of extensive systems fit with one of the three conceptual frameworks used to assess animal welfare, "natural living," and also has clear links to similar concepts in the "five freedoms"-freedom to express normal behaviors and the "five domains"-behavioral or interactive restriction $(7,8)$. While the welfare of goats is largely positive when assessed according to natural living (e.g., providing animals with opportunities to play, make their own decisions, or to have positive social relationships) in extensive system may face a range of compromises to their well-being, but principally, these relate to nutritional stress, inadequate water supply, climatic extremes, parasitical diseases, lameness, and inappropriate managing $(5,9)$. Grazing goats are therefore exposed to a huge diversity of parasites since natural pastures are the main source of internal and external parasites (10). These parasites impact greatly on animal health, welfare, and productivity such as a considerable decline in weight gain, milk yield, and hair coat condition (10).

This paper aims to present the first outcomes of data collected in a sample of extensively reared native Balkan and Serbian white goat according to the AWIN protocol, and parasite data, as well as to identify the welfare problems that affect these animals.

\section{MATERIALS AND METHODS}

\section{Farms and Management}

The study was conducted in January 2021, on four small farms of native Balkan and Serbian white goat (Figures 1A,B). In Table 1, characterizations of the farms are shown. Farms are located in the hilly, mountainous regions of Central and Eastern Serbia (Figure 2). Serbia is a continental country in Southeastern Europe, in the central part of the Balkan Peninsula, between $41^{\circ} 53^{\prime}$ and $46^{\circ} 11^{\prime} \mathrm{N}$ and $18^{\circ} 49^{\prime}$ and $23^{\circ} 00^{\prime} \mathrm{E}$. Due to the Pannonian Plain in the north, it is a part of Central Europe. Geographically and climatically, its southern part is a Mediterranean country. The Serbian climate is between a continental climate in the north, with cold dry winters, and warm, humid summers with well-distributed rainfall patterns, and a more Mediterranean climate in the south with hot, dry summers and autumns and average relatively cool and rainier winters with heavy mountain snowfall. January is the coldest month of the year in Serbia as the winter brings snow, heavy frost, and dense fog in many parts of the country. According to the Republic Hydrometeorological Service of Serbia, the average monthly air temperature for the period in January 2021 was in the range of from $-0.7^{\circ} \mathrm{C}$ to $4.3^{\circ} \mathrm{C}$ (in mountain regions $-5.2^{\circ} \mathrm{C}$ ) with a total of $75-150 \mathrm{~mm}$ precipitation in Central and Eastern Serbia.

Animals from these areas were maintained under extensive management systems, where they foraged all day round in a fenced paddock during the day with minimum supplementation in the winter season ( $1 \mathrm{~kg}$ of a prepared meal of forage legumes + maize per animal). Water is provided from a natural spring, and shelter is provided by trees, shrubs, other vegetation, and artificial
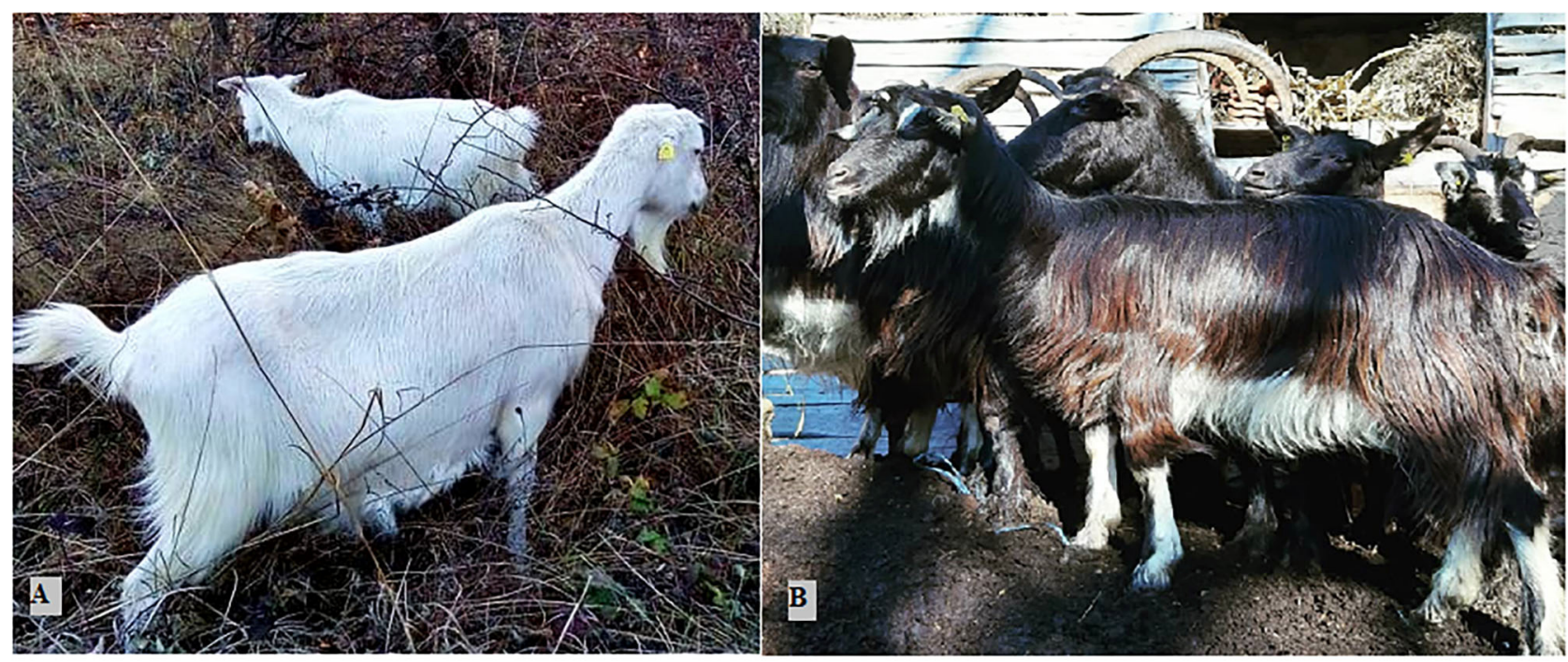

FIGURE 1 | Serbian white (A) and Balkan goat (B) 
TABLE 1 | Characteristics of the examined farms.

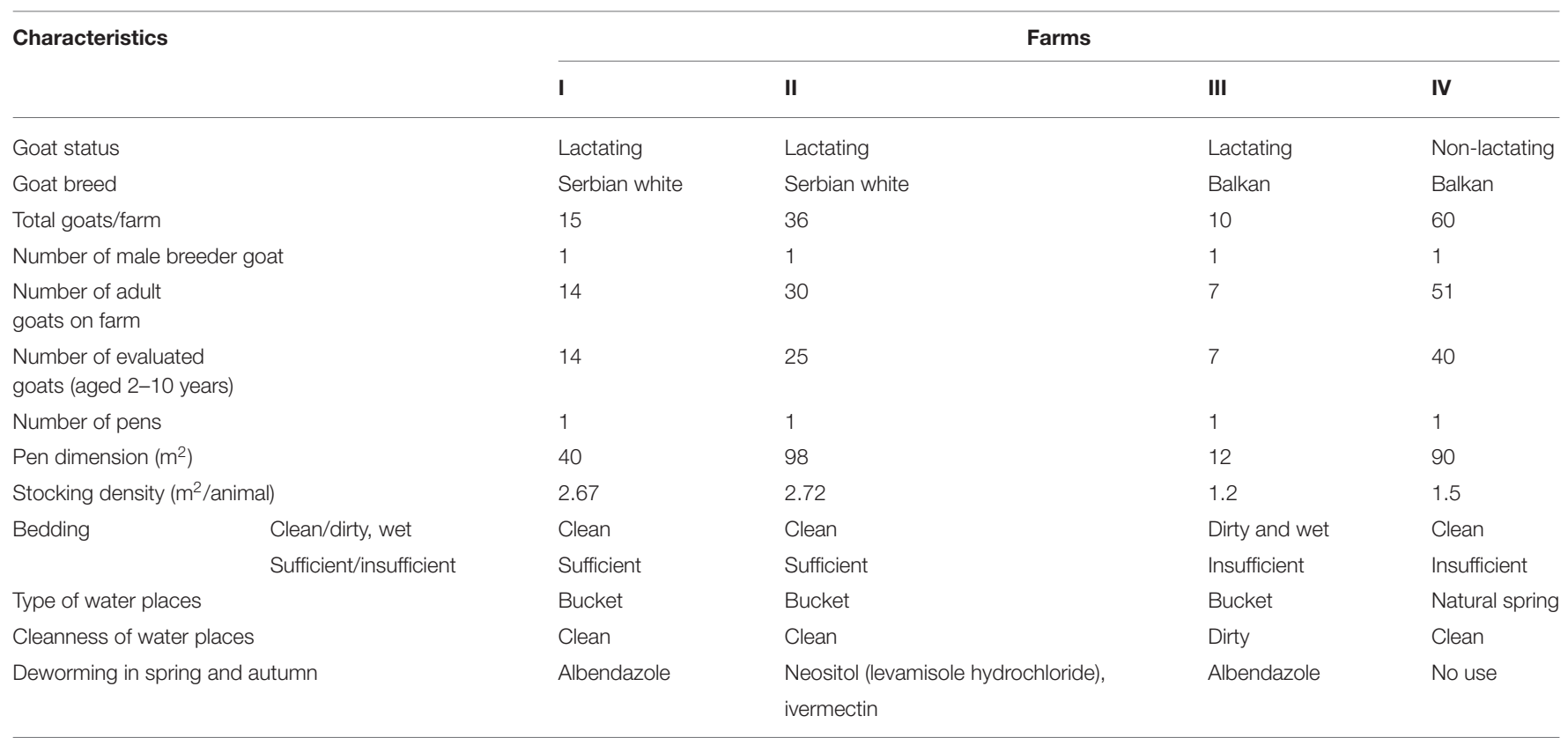

structures. During the winter season at night and the varying climatic extremes, goats are penned. In these areas, farmers use veterinary service (farm II), weak use (farm I and III), and do not use (farm IV) with goats not treated/dewormed (Table 1). An initial preventive planned deworming of animals against intestinal parasites was performed twice a year in spring and autumn (farms I, II, and IV).

\section{Animals and Welfare Assessment}

Since there was no specific protocol for extensively managed goats, the authors used animal-based indicators from AWIN welfare assessment protocol for sheep and goats (11) such as body condition score (BSC), hindquarters cleanness (12), hair coat condition, severe lameness, abscesses, udder asymmetry, oblivion, ocular and nasal discharge, latency to the first contact test and resource-based indicators such as bedding (sufficient/insufficient and clean/dirty, wet) and type and cleanness of water places. These indicators were selected because they address the main welfare concerns for goats, covering freedom from hunger, pain, injury, or disease. The assessment of the goats was conducted between 9 and $16 \mathrm{~h}$ by two assessors who were trained to use AWIN welfare protocol for sheep and goats. Welfare indicators are awarded with a score of 0 when welfare is good, a score of 1 is awarded when welfare has been poor and unacceptable, and a score of -1 is only awarded when the goat is thin.

The total number of goats on the farms was 131 (Table 1). We observed only adult goats aged 2-10 years, and a number of animals for assessment were selected (Table 1) according to the total number of animals on each farm (11).

\section{Parasitological Examinations}

In February 2021, parasitological examinations were performed at the Department of Parasitology, University of Belgrade Faculty of Veterinary Medicine, on fecal samples of native Balkan goat and Serbian white goat from four small farms. Coprological testing included both macroscopic and microscopic examinations of samples. Individual samples were collected from the same housing unit, regarding housing systems.

\section{Sample Collections}

The parasitological examination included the collection of goat feces, in the form of individual samples, which were put in PVC bags, and all the necessary information was labeled. Feces were sampled immediately after defecation. In order to avoid contamination of samples with pseudoplastic particles of plant and animal origin from the litter and the ground, sampling was performed from the upper segments of the excreted feces. The samples were stored in a handheld refrigerator at a temperature of $+4^{\circ} \mathrm{C}$ and transported to the Parasitology Laboratory, where coprological diagnostics was performed within $24 \mathrm{~h}$.

\section{Macroscopic Examination}

In the macroscopic examination, the formation, consistency, color, and odor of fecal samples were investigated. Any deviations in these parameters from the typical physiological characteristics of the feces of the goats were noted. The presence of impurities such as blood, pus, mucus, or undigested food was recorded as potential markers of certain pathological conditions of the gastrointestinal tract. Thereafter, the feces was carefully examined using tweezers, and any adult helminths and their parts were transferred to a Petri dish, rinsed in saline, and prepared for further analysis (13). 


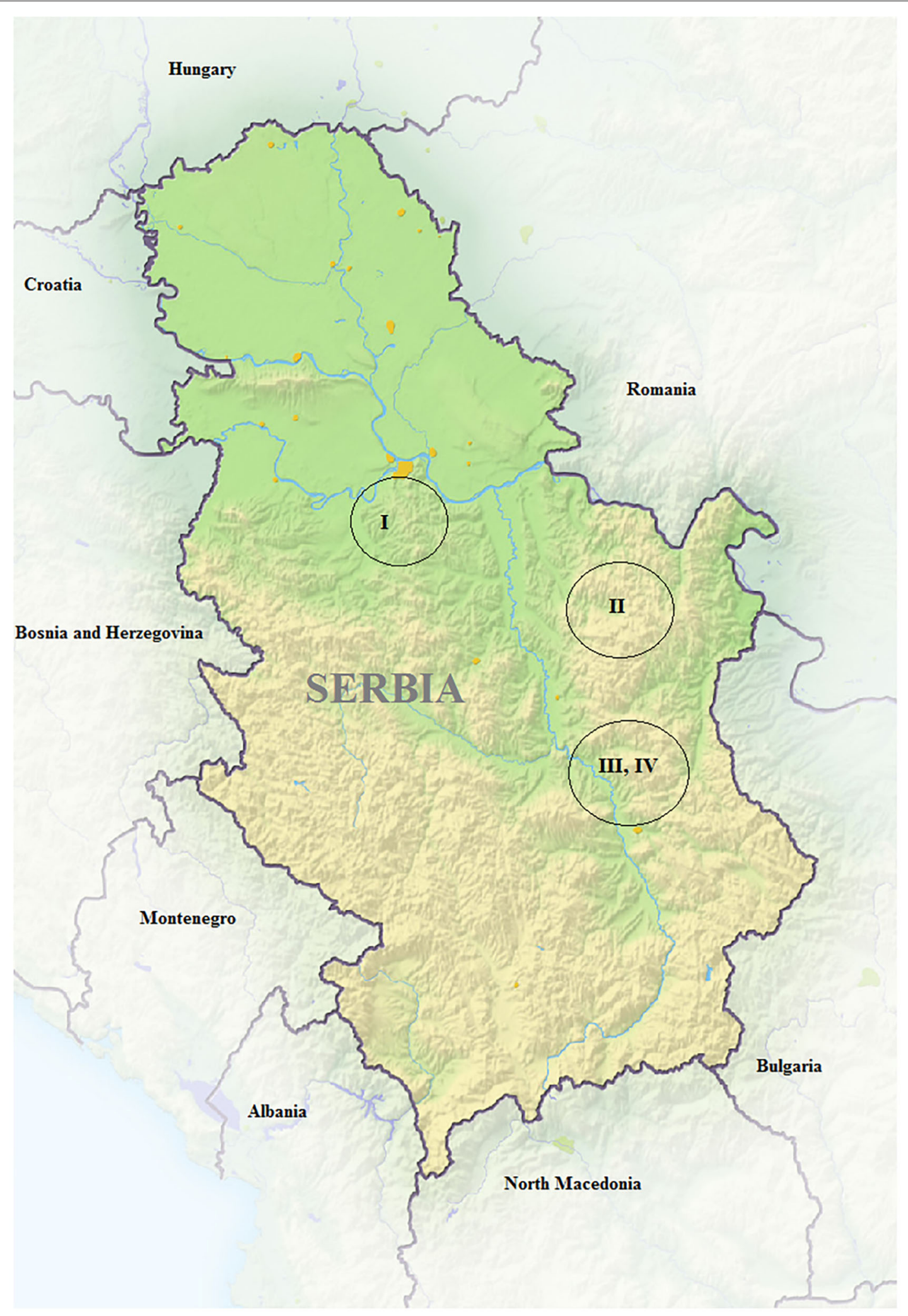

FIGURE 2 | Geographic position of farms included in the survey. 


\section{Microscopic Examination}

Preparations for microscopic diagnostics were made by qualitative methods without concentration and with a concentration of parasitic elements.

\section{Fecal Examination by Qualitative Method}

Coprological examination was performed by qualitative methods without (Vajda method) and with a concentration of parasitic elements-flotation and sedimentation techniques (14).

\section{Fecal Examination by Quantitative Method}

Quantification of the obtained results was performed by the McMaster method (15), with a sensitivity of 50 eggs/oocysts per gram of feces to determine the helminth eggs/coccidia oocyst/ciliate cysts per gram outputs (16).

A saturated aqueous $\mathrm{NaCl}$ solution (>97\%; Roth, Karlsruhe, Germany) was used to perform conventional flotation methods, which was prepared by mixing $210 \mathrm{~g}$ of $\mathrm{NaCl}$ with $1,000 \mathrm{ml}$ of distilled water (specific gravity 1,200). The preparations made were observed under 100 magnifications for morphological identification of gastrointestinal (GI) parasitic eggs/oocysts/cysts, according to Soulsby (17).

Pulmonary strongylids were identified, based on the morphological characteristics of the first-stage larvae.

During the identification of the larvae, the presence of Dictyocaulus filaria was confirmed by the finding of the firststage larvae with an anterior protoplasmic knob and black granular intestinal inclusions in the feces (18). The larvae of Protostrongylides are differentiated by their characteristic feature at the tip of their tail (19).

\section{Statistical Analysis}

Data were analyzed using GraphPad Prism software. Results were described by descriptive statistics (mean value and standard error) and as prevalence (the overall number of goats showing the measure regardless of severity). The distribution of the welfare indicators was tested by the Kolmogorov-Smirnov distribution fitting test, which showed a not normal distribution. The differences between welfare indicators were analyzed using the non-parametric Kruskal-Wallis test on the equality of the medians, adjusted for ties. When significant differences were found, Dunn-Bonferroni post-hoc test was performed. For animal-based parameters and different endoparasite infection and coinfections, the prevalence was calculated on a total number of goats, and the significant difference was determined by the Chi-square test.

Relationships between the different welfare indicators and endoparasites were examined by Spearman's rank correlation. For all correlation analyses, the absolute value of the Spearman's correlation coefficients assessed whether very weak $(0.0 \leq$ $\mid$ rho $\mid<0.2)$, weak $(0.2 \leq \mid$ rho $\mid<0.4)$, moderate $(0.4 \leq$ $\mid$ rho $<0.6)$, strong $(0.6 \leq \mid$ rho $\mid<0.8)$, or very strong $(0.8 \leq \mid$ rho $\leq 1.0)$ relationships existed as described by Campbell (20). Only those correlations significant at $p<0.05$ are reported.

\section{RESULTS}

\section{Welfare Assessment}

Based on the results, significant differences $(p<0.05, p<0.001)$ were observed at body condition score (thin and fat goats), hair coat condition, nasal discharge, severe lameness, and hindquarter cleanness between goats from different farms (Table 2). The most poor and unacceptable welfare indicators in goats were hair coat condition $(62.79 \%, 54 / 86)$ with an average score of 0.63 \pm 0.03 , hindquarter cleanness $(31.40 \%, 27 / 86,0.31 \pm 0.05)$, tin BCS (26.74\%, 23/86, $0.41 \pm 0.07)$, abscesses (19.78\%, 17/86, 0.20 $\pm 0.04)$, and udder asymmetry $(18.60 \%, 16 / 86,0.19 \pm 0.04)$ (Tables 2, 3).

The average score of dirty hair in farm III $(0.86 \pm 0.14)$ and farm IV $(0.40 \pm 0.08)$ was significantly higher $(p<0.001)$ compared with farm II (Table 3).

\section{Parasitological Examinations}

In the examined feces of goats from four farms, nine endoparasites were identified in the form of coinfectionsprotozoa (Coccidia and Buxtonella sulcata), nematodes (Strongylidae, Trichuris ovis, Capillaria spp., Dictyocaulus filaria, and Protostrongylidae), cestodes (Moniezia spp.), and trematodes Dicrocoelium lanceolatum with a total prevalence of $100 \%$ $(86 / 86)$ (Table 4). The most prevalent endoparasites in all farms observed was Coccidia $(95.35 \%, 82 / 86)$ followed by Strongylidae (90.70\%, 78/86) and Protostrongylidae (86.04\%, 74/86).

In farm $\mathrm{I}$, the most prevalent coinfections were $T$. ovisMoniezia spp.-Coccidia-Protostrongylidae and Strongylidae-T. ovis-Moniezia spp.-Coccidia-B. sulcata with prevalence of $21.42 \%$ (3/14). Polyparasitism of Strongylidae-CoccidiaProtostrongylidae dominated in farm II $(48 \%-12 / 25)$ and farm IV $(40 \%-14 / 40)$, while on farm III prevailing coinfections were Strongylidae-T. ovis-Moniezia spp.-Protostrongylidae $(28.57 \%-2 / 7)$ (Table 5). A significant difference $(p<0.05 ; p$ $<0.001$ ) between four farms of extensively managed native goat breed was established in the prevalence of all coinfections except in quadruple infections of Strongylidae-Moniezia spp.-Coccidia-Protostrongylidae (Table 5).

In most fecal samples of goats, we detected a low degree of infection ( $<50-500 \mathrm{opg} / \mathrm{epg})$ with coccidia, strongylidae, anoplocephalidae, and T. ovis (farms I, II, and III), coccidia and strongylidae (farm II), and Capillaria spp. (farm IV) (Table 6). Medium degree of infection (550-1,500 opg/epg) with coccidia was found in farm I ( $875 \pm 25 \mathrm{opg})$, farm II $(1,000 \pm 22.60 \mathrm{opg})$, and farm III (733.3 $\pm 109.3 \mathrm{opg})$. The high degree of infection ( $>1,500 \mathrm{opg} / \mathrm{epg}$ ) was with coccidian and was detected only in farm II (1,975 \pm 141.70 opg) (Table 6).

\section{Correlations Between Welfare Indicators and Endoparasites}

Table 7 shows the significant correlations observed between the different welfare indicators and different endoparasites. There was a weak significant positive correlation between BCS and hair coat condition ( $r h o=0.28, p<0.001$ ) and a moderate positive correlation between bedding cleanness and dirty and light soiling hindquarters (rho $=0.35, p<0.001$ ) and bedding cleanness 
TABLE 2 | Prevalence of welfare parameters in 86 individual goats examined in four farms in Serbia.

\begin{tabular}{|c|c|c|c|c|c|c|c|c|c|c|c|c|c|}
\hline \multicolumn{2}{|c|}{ Animal-based indicators } & \multicolumn{12}{|c|}{ Farms } \\
\hline & & \multicolumn{2}{|c|}{$\begin{array}{c}\text { I } \\
N=14\end{array}$} & \multicolumn{2}{|c|}{$\begin{array}{c}\text { II } \\
N=25\end{array}$} & \multicolumn{2}{|c|}{$\begin{array}{c}\text { III } \\
N=7\end{array}$} & \multicolumn{2}{|c|}{$\begin{array}{c}\text { IV } \\
N=40\end{array}$} & \multicolumn{2}{|c|}{$\begin{array}{c}\text { Total for } \\
\text { all farms } \\
N=86\end{array}$} & \multirow[t]{2}{*}{$\chi^{2}$} & \multirow[t]{2}{*}{$p$} \\
\hline & & $n$ & $\%$ & $n$ & $\%$ & $n$ & $\%$ & $n$ & $\%$ & $N$ & $\%$ & & \\
\hline Body condition & Thin & 8 & 57.14 & 7 & 28 & 2 & 28.57 & 6 & 15 & 23 & 26.74 & 8.32 & $0.03^{*}$ \\
\hline \multirow[t]{2}{*}{ score (BCS) } & Adequate & 6 & 42.86 & 18 & 72 & 5 & 71.43 & 28 & 70 & 57 & 66.28 & 4.13 & 0.25 \\
\hline & Fat & 0 & 0 & 0 & 0 & 0 & 0 & 6 & 15 & 6 & 15 & 7.42 & $0.05^{\star}$ \\
\hline \multicolumn{2}{|c|}{ Hair coat condition } & 13 & 92.85 & 12 & 48 & 5 & 71.43 & 24 & 60 & 54 & 62.79 & 8.12 & $0.04^{*}$ \\
\hline \multicolumn{2}{|c|}{ Severe lameness } & 0 & 0 & 0 & 0 & 2 & 28.57 & 0 & 0 & 2 & 2.33 & 23.10 & $0.00^{\star * *}$ \\
\hline \multicolumn{2}{|l|}{ Abscesses } & 5 & 35.71 & 3 & 12 & 1 & 14.29 & 8 & 20 & 17 & 19.78 & 3.33 & 0.34 \\
\hline \multicolumn{2}{|c|}{ Hindquarters cleanness } & 5 & 35.71 & 0 & 0 & 6 & 85.71 & 16 & 40 & 27 & 31.40 & 22.53 & $0.00^{\star * \star}$ \\
\hline \multicolumn{2}{|c|}{ Udder asymmetry } & 3 & 21.43 & 3 & 12 & 1 & 14.29 & 9 & 22.5 & 16 & 18.60 & 1.28 & 0.73 \\
\hline \multicolumn{2}{|l|}{ Nasal discharge } & 3 & 21.43 & 2 & 8 & 0 & 0 & 1 & 2.5 & 6 & 6.98 & 7.16 & 0.09 \\
\hline \multicolumn{2}{|c|}{ Ocular discharge } & 0 & 0 & 0 & 0 & 0 & 0 & 0 & 0 & 0 & 0 & / & / \\
\hline \multicolumn{2}{|l|}{ Oblivion } & 1 & 7.14 & 0 & 0 & 1 & 14.29 & 0 & 0 & 2 & 2.33 & 7.39 & 0.06 \\
\hline
\end{tabular}

$N$, total number of samples; $n$, number of positive samples. ${ }^{* * *} p<0.001 ;{ }^{*} p<0.05$.

TABLE 3 | Mean ( \pm SEM) scores for animal-based welfare parameters in goats examined in four farms in Serbia.

\begin{tabular}{|c|c|c|c|c|c|c|}
\hline \multirow[t]{3}{*}{ Animal-based indicators } & \multicolumn{6}{|c|}{ Farms } \\
\hline & $\mathbf{I}$ & II & III & IV & Total for all farms & $p$ \\
\hline & Mean \pm SEM & Mean \pm SEM & Mean \pm SEM & Mean \pm SEM & Mean \pm SEM & \\
\hline Body condition score (BCS) & $0.57 \pm 0.14$ & $0.28 \pm 0.09$ & $0.29 \pm 0.18$ & $0.45 \pm 0.12$ & $0.41 \pm 0.07$ & 0.55 \\
\hline Hair coat condition & $0.93 \pm 0.07$ & $0.48 \pm 0.06$ & $0.71 \pm 0.18$ & $0.60 \pm 0.08$ & $0.63 \pm 0.03$ & 0.13 \\
\hline Severe lameness & 0 & 0 & $0.29 \pm 0.18$ & 0 & $0.02 \pm 0.02$ & 0.67 \\
\hline Abscesses & $0.36 \pm 0.13$ & $0.12 \pm 0.07$ & $0.14 \pm 0.14$ & $0.20 \pm 0.06$ & $0.20 \pm 0.04$ & 0.66 \\
\hline Hindquarters cleanness & $0.36 \pm 0.13$ & $\mathrm{O}^{\mathrm{AB}}$ & $0.86 \pm 0.14^{A}$ & $0.40 \pm 0.08^{\mathrm{B}}$ & $0.31 \pm 0.05$ & $0.00^{\star * *}$ \\
\hline Udder asymmetry & $0.21 \pm 0.11$ & $0.12 \pm 0.07$ & $0.14 \pm 0.14$ & $0.23 \pm 0.07$ & $0.19 \pm 0.04$ & 0.90 \\
\hline Nasal discharge & $0.21 \pm 0.11$ & $0.08 \pm 0.06$ & 0 & $0.03 \pm 0.02$ & $0.06 \pm 0.03$ & 0.10 \\
\hline Ocular discharge & 0 & 0 & 0 & 0 & 0 & 0 \\
\hline Oblivion & $0.07 \pm 0.07$ & 0 & $0.14 \pm 0.14$ & 0 & $0.02 \pm 0.02$ & 0.92 \\
\hline
\end{tabular}

${ }^{* \star *} p<0.001 ;{ }^{A, B} p<0.001$.

and severe lameness ( $r h o=0.51, p<0.001$ ). Likewise, a weak significant correlation between strongylids, anoplocephalids, Buxtonella sulcata, and hair coat condition ( $\mathrm{rho}=0.23, \mathrm{r}=0.21$, rho $=0.25$, respectively, $p<0.05$ ) were observed (Table 7 ), and week significant negative correlation between protostrongilids and nasal discharge (rho $=-0.28, p<0.001$ ).

\section{DISCUSSION}

Although we examined four farms and 86 extensively managed native goat breed in total, this study constitutes the first evaluation of the welfare of goats conducted in Serbia. The findings of this study are a sound basis for future research, providing valuable insight into the main welfare issues regarding extensive goat farming. Poor hair coat condition (62.79\%), dirty and light soiling hindquarters (31.40\%), thin BCS (26.74\%), abscesses (19.78), and udder asymmetry (18.60\%) showed high prevalence and should, therefore, be considered as major welfare problems.

In the present study, we observed a total of $66.28 \%$ of the goats were in adequate BCS, but the presence of the 26.74 and $15 \%$ thin and fat goats represent factors affecting welfare in those animals. These results can be ascribed to the fact that in extensive systems, goats due to seasonal variation and not timely grazing sometimes cope with long periods of grazing the forage with high fiber contents and low energy, and suffer chronic hunger (6). Even the food supplementation was provided by all farmers from the study; problems with inadequate body condition scores occurred. An additional problem with supplementation is that we can connect that some animals may be reluctant to eat the supplements if they are not accustomed to them, or there might be existing competition between animals (6). The importance 
TABLE 4 | Prevalence of endoparasites in goats examined in four farms in Serbia.

\begin{tabular}{|c|c|c|c|c|c|c|c|c|c|c|c|c|}
\hline \multirow[t]{2}{*}{ Endoparasites } & \multicolumn{2}{|r|}{$\begin{array}{c}I \\
(N=14)\end{array}$} & \multicolumn{2}{|c|}{$\begin{array}{c}\text { II } \\
(N=25)\end{array}$} & \multicolumn{2}{|r|}{$\begin{array}{c}\text { III } \\
(N=7)\end{array}$} & \multicolumn{2}{|c|}{$\begin{array}{c}\text { IV } \\
(N=40)\end{array}$} & \multicolumn{2}{|c|}{$\begin{array}{c}\text { Total } \\
(\mathbf{N}=86)\end{array}$} & \multirow[t]{2}{*}{$\chi^{2}$} & \multirow[t]{2}{*}{$p$} \\
\hline & $n$ & $\%$ & $n$ & $\%$ & $n$ & $\%$ & $n$ & $\%$ & $n$ & $\%$ & & \\
\hline S & 9 & $\begin{array}{c}64.29 \\
(39.19-89.39)\end{array}$ & 25 & 100 & 5 & $\begin{array}{c}71.43 \\
(37.96-100)\end{array}$ & 39 & $\begin{array}{c}97.50 \\
(95.13-100)\end{array}$ & 78 & 90.70 & 9.41 & $\star \star \star *$ \\
\hline $\mathrm{T}$ & 10 & $\begin{array}{c}71.43 \\
(47.77-95.09)\end{array}$ & 0 & 0 & 4 & $\begin{array}{c}57.14 \\
(20.48-93.80)\end{array}$ & 15 & $\begin{array}{c}37.50 \\
(22.50-52.50)\end{array}$ & 29 & 33.72 & 23.6 & *** \\
\hline M & 10 & $\begin{array}{c}71.43 \\
(47.77-95.09)\end{array}$ & 0 & 0 & 6 & $\begin{array}{c}85.71 \\
(59.79-100)\end{array}$ & 16 & $\begin{array}{c}40 \\
(24.82-55.18)\end{array}$ & 32 & 37.21 & 29.01 & 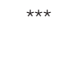 \\
\hline C & 14 & 100 & 25 & 100 & 5 & $\begin{array}{c}71.43 \\
(37.96-100)\end{array}$ & 39 & $\begin{array}{c}97.50 \\
(95.13-100)\end{array}$ & 82 & 95.35 & 53.31 & 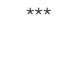 \\
\hline$C^{1}$ & 0 & 0 & 0 & 0 & 0 & 0 & 6 & $\begin{array}{c}15 \\
(3.93-26.07)\end{array}$ & 6 & 6.98 & 7.14 & * \\
\hline$D$ & 2 & $\begin{array}{c}14.29 \\
(0-32.62)\end{array}$ & 4 & $\begin{array}{c}16 \\
(1.63-30.37)\end{array}$ & 0 & 0 & 9 & $\begin{array}{c}22.50 \\
(9.56-35.44)\end{array}$ & 15 & 17.44 & 2.32 & 0.50 \\
\hline BS & 7 & $\begin{array}{c}50 \\
(23.81-76.19)\end{array}$ & 0 & 0 & 0 & 0 & 0 & 0 & 7 & 8.14 & 39.01 & 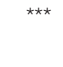 \\
\hline$P$ & 9 & $\begin{array}{c}64.29 \\
(39.19-89.39)\end{array}$ & 20 & $\begin{array}{c}80 \\
(64.32-95.68)\end{array}$ & 6 & $\begin{array}{c}85.71 \\
(59.79-100)\end{array}$ & 39 & $\begin{array}{c}97.50 \\
(95.13-100)\end{array}$ & 74 & 86.04 & 10.65 & 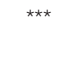 \\
\hline$D^{1}$ & 0 & 0 & 8 & 32 & 0 & 0 & 0 & 0 & 8 & 9.30 & 21.52 & $\star \star \star ~$ \\
\hline
\end{tabular}

$N$, total number of samples; $n$, number of positive samples; $S$, Strongylidae; C, Coccidia; T, Trichuris ovis; M, Moniezia spp.; $C^{1}$, Capillaria spp.; $D$, Dicrocoelium lanceolatum; ${ }^{1}$, Dictyocaulus filarial; B, Buxtonella sulcata; $P$, Protostrongylidae. ${ }^{\star \star \star} p<0.001 ;{ }^{*} p<0.05$.

of dietary supplementation, especially protein supplementation, showed in numerous studies on resistance and resilience of sheep and goats to GI parasite infections, has been recently confirmed in a few studies $(21,22)$. According to Hoste et al. (23), GI parasitic infection is often equated to a nutritional disease because of the major negative impacts on total tract digestibility, diet intake, and the reorientation of nutrient use for the maintenance of tissue homeostasis. Ghosh et al. (24) reported that the nutritional status of goats is influenced by a number of factors such as feeding strategy and management, health (parasites, wasting disease, and viral or bacterial and metabolic diseases), age, social hierarchy, and goat status.

Among the etiological agents that affect the poor health status of goats, parasites are usually neglected, although they can lead to colossal morbidity and mortality of goats, which results in significant economic losses (25-27). In our study, the overall prevalence of endoparasites in goats from four farms was $100 \%$ and might represent a factor that affects body condition score. Although in our study we did not find that BCS and endoparasites correlated, according to many authors (28-33), endoparasites cause several subclinical effects such as hyperproteinemia, growth depression, reduction in milk yield, loss of appetite, and digestive inefficiency. Parasite infection negatively affects hosts by consuming host resources and directly damaging host tissues or indirectly by stimulating costly immune responses and by changing host movement, foraging, or social behaviors (34-36).

Polyparasitism in our study might be due to goat grazing activities on contaminated pastures, poor sanitation and management in farm III, unsystematic and inadequate deworming, or not treating in farm IV (Table 1).
We noted that the overall prevalence of coccidian oocysts in goats was $95.35 \%$. Our results are similar to those reported in China-87.9\% (37), Czech Republic-92.2\% (38), Portugal-100\% (39), and Slovakia-100\% (40). The high prevalence of coccidian oocysts in studied animals might be linked with the poor hair coat condition since coccidia can invade and destroy intestinal cells of the hosts, and electrolyte loss exacerbates mineral deficiencies, and there is poor absorption of nutrients, and affected goats can show a rough hair coat, poor weight gain, and weakness $(37,41)$.

The current finding showed that $100 \%$ of the studied animals were positive with GI parasitic infection, predominated by coccidian oocysts and strongyloides eggs (90.70\%) with a low degree of infections. These data indicates that all diagnosed endoparasitosis in extensively managed goats are mostly present in the subclinical form. As a consequence, infective agents mainly cause indirect economic damage to the extensively managed goat production and significantly affect the welfare of goats. Polyparasitism was found in all goats, which can compromise the immune system of the host increasing their susceptibility to other diseases or parasites (42). Similar surveys of parasites on goat farms have been conducted in other European and Asian countries. Eggs from one or more species of GI parasites were identified in $100 \%$ goats in Turkey (43), $95.90 \%$ in Slovakia (44), 87.95\% in Nepal (45), and 96\% in Northern Italy (46).

Another parasite, Capillaria spp. was currently reported to be a prevalence rate $(6.98 \%)$ that was higher than reported in Italy (46), Nepal (45), Bangladesh (47), and Thailand (48) (lower than $2 \%)$. Capillaria spp. is critical in goats and shares a wide range of herbivores including man (49). 
TABLE 5 | Prevalence of coinfection parasite infections in goats examined in four farms in Serbia.

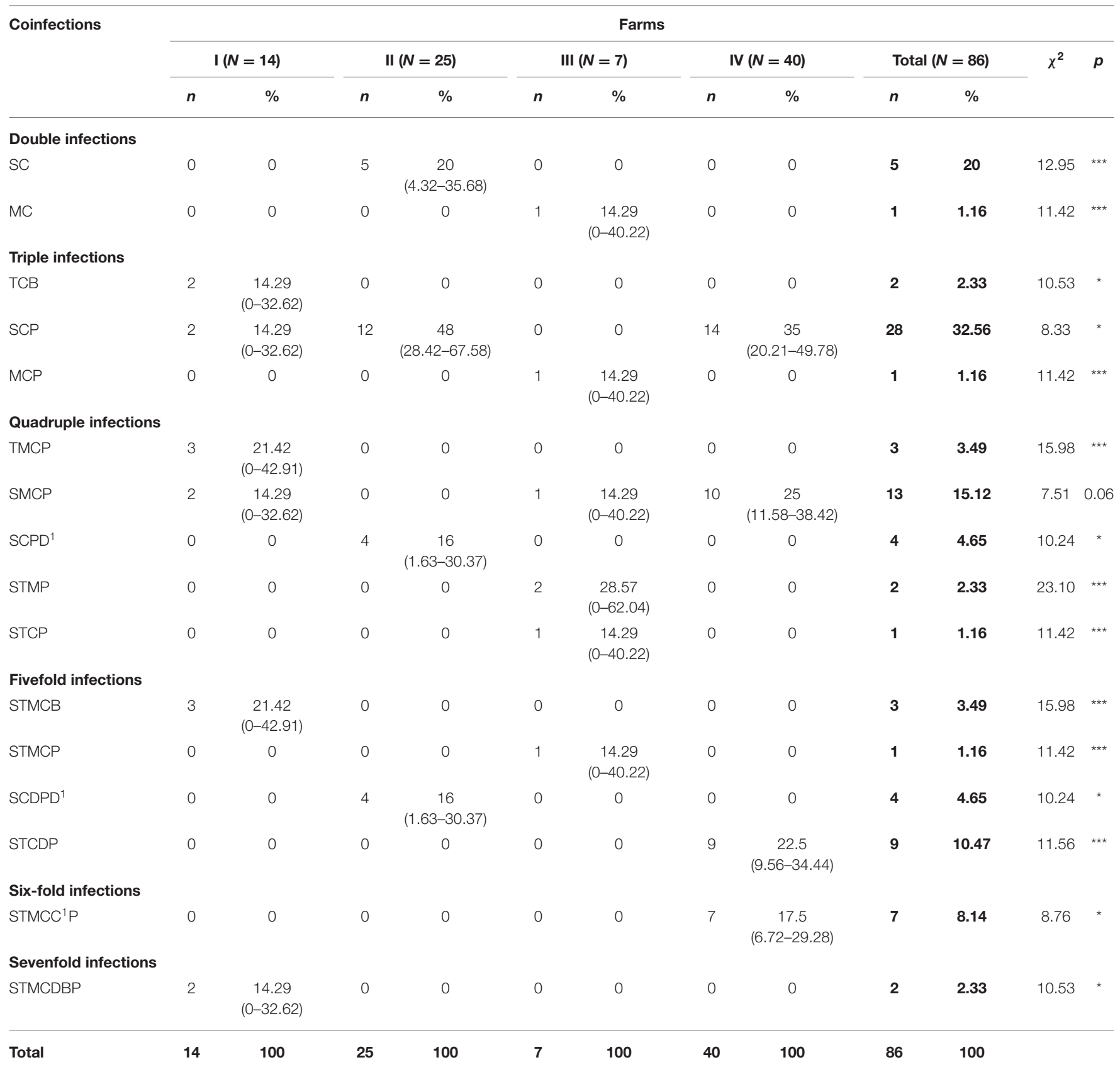

N, total number of samples; $n$, number of positive samples; $S$, Strongylidae; $C$, Coccidia; T, Trichuris ovis; $M$, Moniezia spp.; $C^{1}$, Capillaria spp.; $D$, Dicrocoelium lanceolatum; $D^{1}$, Dictyocaulus filarial; $B$, Buxtonella sulcata; $P$, -Protostrongylidae.

${ }^{\star \star \star} p<0.001 ;{ }^{*} p<0.05$.

The current study identified the overall prevalence of $37.21 \%$ (Moniezia spp.), $33.72 \%$ (T. ovis), $17.44 \%$ (D. lanceolatum), and $8.14 \%$ (B. sulcata), significantly higher than those reported by other researchers $(44,46)$, and in agreement with results from Nepal (45).

According to authors from Ethiopia (50) and West Africa (51), the prevalence of moniesiosis in sheep is significantly higher compared with goats and more susceptible to parasite infection (52). Infection of Moniezia spp. in small ruminants was reported to cause severe pathogenic effects, viz. disturbance of gastrointestinal motility, secretion, diarrhea, and anemia along with reduced slaughter yield, increased water content, and reduction in protein and fat (53).

Dicrocoelium spp. hepatic infection is responsible for direct losses in sheep and goat production due to the discarding of parasitized livers and indirect losses through costs associated with anthelmintic treatments (53). It has been reported in Italy (54), Iran (55), India (56), Nepal (57), Malaysia (58), and 
TABLE 6 | Quantitative assessment of fecal samples in in goats examined on four farms in Serbia.

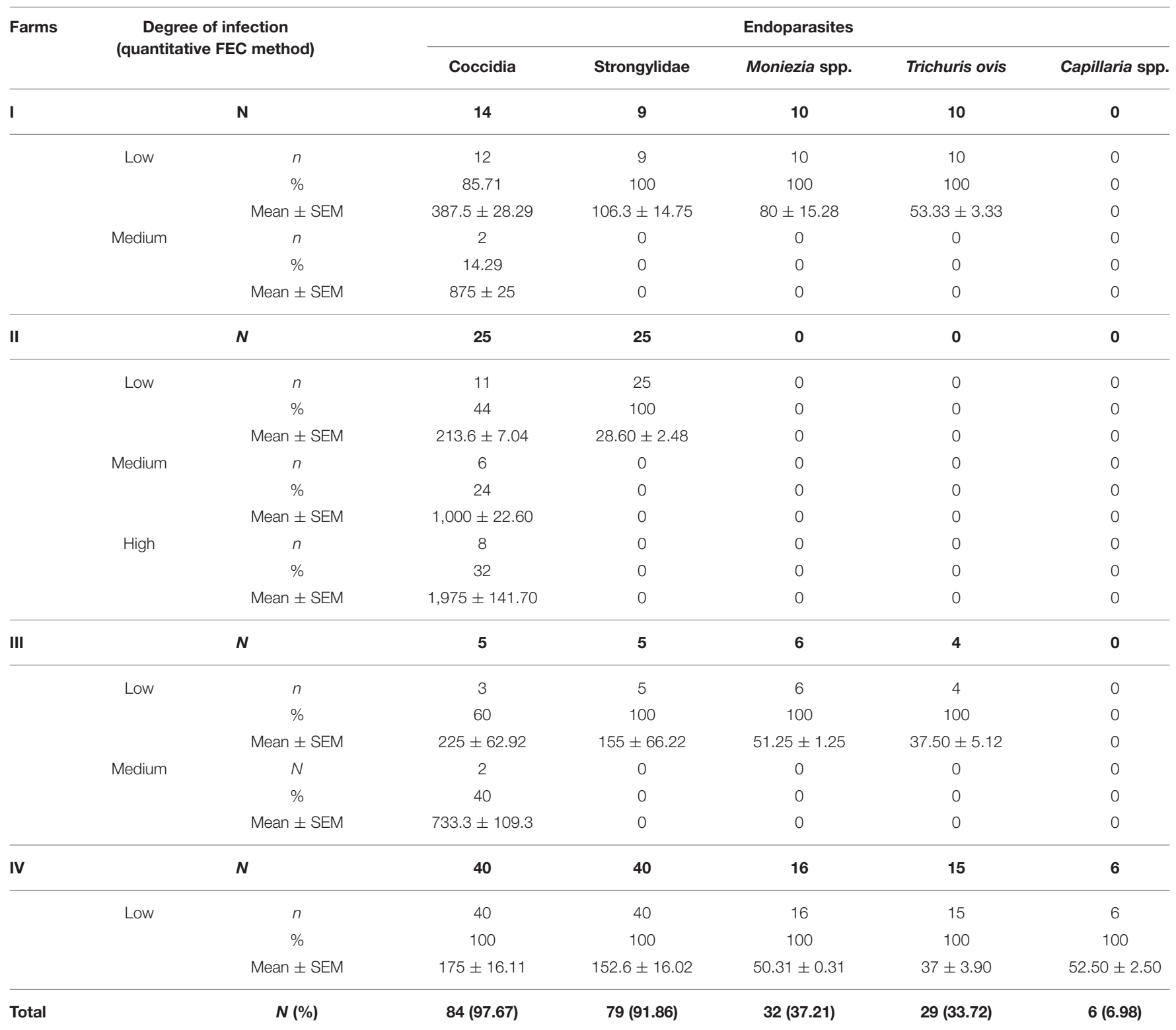

Low: <50-500 opg/epg; medium: 550-1,500 opg/epg; high: > 1,500 opg/epg (opg/epg, number of oocysts/eggs calculated per $1 \mathrm{~g}$ of feces); $N$, total number of samples; $n$, number of positive samples.

Nigeria (59). According to Sharma et al. (53), dicrocoeliosis remained little known and underestimated since those infected are asymptomatic and masked by the presence of pathological effects of multiple parasitic infections in ruminants.

The current finding showed that lungworms, protostrongylide infection predominated $(87.21 \%)$, which is in agreement with the results from Morocco (60), but differs from Ethiopia - 13.4$53.6 \%$ (61). The finding of D. filaria (9.30\%) is in agreement with those recorded by Paran et al. (62) who diagnosed the prevalence at $8.9 \%$. In our study, we found six goats (6.98\%) with nasal discharge and significant correlations with protostrongylidae. These results can be ascribed to the fact that the most common clinical sign of lungworms in sheep and goats are pyrexia, coughing, rapid shallow breathing, nasal discharge, and emaciation with retarded growth (63). Lungworm infections in goats are of considerable economic importance. The parasites cause chronic production losses as a result of reduced food conversion ratio (FCR) and weight gain (62). The variation and differences in the prevalence of lungworms of small ruminants in different areas might be associated with differences in nutritional status, level of immunity, management practice of the animal, rainfall, humidity, temperature, altitude differences (64), and season of examination on their respective study area (65).

Poor hair coat condition was found at a prevalence of around $62.79 \%(54 / 86)$ in all farms. This result is not in agreement with those recorded by Can et al. (66) who found that $20-25 \%$ of the 
TABLE 7 | Spearman's rank correlations between the welfare indicators and different endoparasites.

\begin{tabular}{llcc}
\hline & & rho & $p$ \\
\hline Welfare indicators & & & \\
BCS & Hair coat condition & 0.28 & $0.00^{* * *}$ \\
Bedding cleanness & Hindquarter cleanness & 0.35 & $0.00^{* * *}$ \\
Bedding cleanness & Severe lameness & 0.51 & $0.00^{* * *}$ \\
Endoparasites vs. welfare indicators & & \\
Strongylidae & Hair coat condition & -0.23 & $0.03^{*}$ \\
Moniezia spp. & Hair coat condition & 0.24 & $0.05^{*}$ \\
Buxtonella sulcata & Hair coat condition & 0.25 & $0.02^{*}$ \\
Protostrongylidae & Nasal discharge & -0.28 & $0.00^{* * *}$ \\
\hline
\end{tabular}

${ }^{\star \star \star} p<0.001 ;{ }^{*} p<0.05$.

observed animals showed inadequate poor hair coat condition in intensive dairy goat farms. The available literature suggests that different factors may affect hair coat conditions in goats such as mineral deficiencies (41), lower BCS (67), and ectoparasite infestation (68). According to Battini et al. (67), this indicator can reflect a goat's nutritional and health status. In the present study, we found that BCS and certain endoparasites (Strongylidae, Moniezia spp. and Buxtonella sulcata) correlate weak with hair coat conditions. The finding was not in agreement with the report made by Battini et al. (67), who found no effect of GI parasitic infestation on hair coat condition due to low level of infestation and the no access to pasture that represents one of the main risk factors for gastrointestinal parasite infections (69). These results suggest that parasites are certainly one cause for a poor hair coat condition, although we cannot exclude that other factors may affect this indicator, such as cold temperatures during the winter season. Exposure to hot or cold environments can also be a welfare problem for extensive livestock $(70,71)$. In cold winters, energy requirements for maintenance are $20 \%$ greater (72). A study performed by Battini et al. (67) proved that goats with a rough hair coat were in a significantly poorer nutritional condition and health status compared with goats with a normal hair coat. These indicate that cold weather could indirectly affect poor hair coat conditions in goats with nutritional deficiencies. The previous study (73) have shown that prolonged exposure of goat to naturally occurring or artificially induced cold environments mobilized fatty acids together with the increased blood glucose, which could have been used in muscles for heat production.

In the present study, we noted dirty and light soiling hindquarters in $31.40 \%$ of the studied goats. This result is in agreement with those recorded by Can et al. (66) who found dirty hindquarter prevalence of $27.1 \%$. The result from this study is highly related to immediate environmental conditions, stock attitudes of people, and care for animals (74). According to Bøe et al. (75), the most important characteristics of pen flooring for farm animals are considered to be thermal conductivity, softness, cleanliness, and slipperiness. Even if this welfare indicator was not included in the AWIN welfare protocol for goats (11), dirty hindquarters may reflect animal discomfort that affects the welfare of goats. Based on the results of Bøe et al. (75), the cleanliness of the floor influences animal preferences among others, while softness did not appear to be an important flooring characteristic for the goats. In this study, bedding and hindquarter cleanness were correlated. Also, the dirtiest hindquarters in goats were observed in farm III (85.71\%) compared with other studied farms, reflecting poor management and cleaning routines (Table 1). These findings are unsurprising, as a range of factors, such as housing design and bedding type, affects the cleanliness of goats.

Damp and dirty environments lead to the spread of specific bacteria, which cause painful health problems such as lameness (76). In this study, bedding cleanness and severe lameness were correlated. Generally, the prevalence of obviously severe lameness in goats was very low (only two in farm III, 2.33\%) which is in line with the studies of Anzuino et al. (77), Muri et al. (78), and Can et al. (66), which reported lameness prevalence of $3,1.7$, and $2.1 \%$, respectively. Since lameness is a major welfare concern as it is a painful condition, it is important to identify and treat it (79).

The present study also describes the overall prevalence of abscesses (19.78\%) and udder asymmetry (18.60\%). The occurrence of external abscesses in the body is closely associated with caseous lymphadenitis in small ruminants (80), which is recognized as an endemic disease in many countries (81). According to Mattiello et al. (82), external abscesses may influence the health condition of the animals and behavioral changes. Udder asymmetry is a sign of chronic alteration that remains even after an udder has recovered from infection or injury (83).

The human-animal relationship represents the mutual perception of stockman and animals and is essential for good animal welfare (84). In the present study, the latency period to the first contact between goat and assessor was good on all studied farms. Regarding the studied animals, extensively managed sheep showed fear in relation to the first contact with assessors (85). According to Jackson and Hackett (86) dairy goats habituate faster with human presence and gentle handling with regard to sheep that receive only neutral or aversive contact with people in extensive systems, e.g., restraint, shearing, or medication administration. This appears to support the findings of Mattiello et al. (87) that ascribe the better and very close relationship between the stock person and the animals in small farms compared with large ones.

\section{CONCLUSION}

Although extensive systems of management provide appropriate physical living conditions (e.g., resting area, natural shelters from varying climatic extremes, and grazing area) where goats can express natural behavior, disadvantages in terms of animal welfare exist. Animal-based parameters provide information on the care of farmers for animals. These results demonstrated that the most common causes of further care were poor hair coat condition, dirty hindquarters, thin BCS, abscesses, and udder asymmetry, while other welfare problems are less 
represented such as severe lameness, oblivion, and nasal discharge. In addition, an important and prevalent problem in welfare identified across all farms was parasite infection. Nutritional deficiency and the probable scarcity of quality protein, together with sources of infection during stabling, characterize coccidiosis and T. ovis infections, which directly impact the quality of the hair coat and the body condition of the animals. Therefore, these findings suggest for a need of well-coordinated, sanitary monitoring of goat farms by field veterinarians and dissemination of knowledge to animal handlers and farmers to minimize the occurrence of infections. Overall, the issues identified in this study can be treated or mitigated by management practices. Also, it is recommended that protein supplementation be used, which leads to resistance and resilience of goats to GI parasite infections. While results in this study may be more representative of welfare problems in large-scale goat farms, the findings of this study are groundwork for future research, providing valuable insight into the main welfare issues likely to be encountered in extensive goat farming.

\section{DATA AVAILABILITY STATEMENT}

The raw data supporting the conclusions of this article will be made available by the authors, without undue reservation.

\section{REFERENCES}

1. Maksimović N, RuŽić-Muslić D, Petrović VC, Pantelić V, Cekić B, Cosić I, et al. Performance records of autochthonous goats in central Serbia. Biotechnol Anim Husb. (2019) 35:357-65. doi: 10.2298/BAH1904357M

2. Anonymous. Zakon o zabrani drŽanja koza. SluŽbeni glasnik Narodne Republike Srbije 37:269 (1954).

3. FAOSTAT. Food and Agriculture Organization of the United Nations Statistics Division (2020). Available online at: http://www.fao.org/faostat/en/\# data/QA/visualize (accessed January 5, 2020).

4. Žujović M, Stanišić N, Memiši N. Autochthonous Balkan goat bread composition and traits of kid carcass. Biotechnol Anim Husb. (2009) 25:41120. doi: 10.2298/BAH0906411Z

5. Spigarelli C, Zuliani A, Battini M, Mattiello S, Bovolenta S. Welfare assessment on pasture: a review on animal-based measures for ruminants. Animals. (2020) 10:609. doi: 10.3390/ani10040609

6. Temple D, Manteca X. Animal welfare in extensive production systems is still an area of concern. Front Sustain Food Syst. (2020) 4:154. doi: $10.3389 /$ fsufs.2020.545902

7. Fraser D. Assessing animal welfare at the farm and group level: the interplay of science and values. Anim Welf. (2003) 12:433-43.

8. Mellor D, Beausoleil N. Extending the "five domains" model for animal welfare assessment to incorporate positive welfare states. Anim Welf. (2015) 24:241-53. doi: 10.7120/09627286.24.3.241

9. Turner SP, Dwyer CM. Welfare assessment in extensive animal production systems: challenges and opportunities. Anim Welf. (2007) 16:189-92.

10. Kumar N, Rao TK, Varghese A, Rathor VS. Internal parasite management in grazing livestock. J Parasit Dis. (2013) 37:151-7. doi: $10.1007 / \mathrm{s} 12639-012-0215-\mathrm{z}$

11. Mattiello S, Battini M, Vieira A, Stilwell, G. AWIN Welfare assessment protocol for goats. (2015)

12. Dwayer C, Ruiz R, Heredia IBD, Canali E, Barbieri S, Zanella A. AWIN Welfare assessment protocol or sheep. (2015). doi: 10.13130/AWIN_SHEEP_2015

13. Dimitrijević S. Dijagnostika parazitskih bolesti (Diagnosis of parasitic diseases). Beograd: Fakultet veterinarske medicine (1999).

\section{ETHICS STATEMENT}

Ethical review and approval was not required for the animal study because the research was not conducted directly on animals, we only observed animals and sampled from them (feces). In this way, the welfare of the examined individuals was not impaired. Written informed consent for participation was not obtained from the owners because we made an agreement over the phone that their farms would remain anonymous as we complied.

\section{AUTHOR CONTRIBUTIONS}

$\mathrm{KN}$ wrote the manuscript with input from all authors. $\mathrm{KN}$ and MV conceptualized and designed the study. TI and NJ acquired, analyzed, and interpreted the data. DB made critical revisions. All authors contributed to the article and approved the submitted version.

\section{FUNDING}

We gratefully thank to Frontiers Financial Support (Grant No. DSC-03030774116PRD) and Frontiers Strategic Budget (Grant No. DSC-08031481405PRD). We gratefully thank to Mivaka d.o.o. for financial support.
14. Fisheries MAFF. Food, Reference Book: Manual of Veterinary Parasitological Laboratory Techniques. London: Ministry of Agriculture (1986).

15. Chandrawathani P, Premaalatha B, Jamnah O, Priscilla FX, Erwanas AI, Lily Rozita MH, et al. Mc Master method of worm egg count from faecal samples of goats: A comparison of single and double chamber enumeration of worm eggs. MJVR. (2015) 6:81-7.

16. Urquhart GM, Armour J, Duncan JL, Dunn AM, Jennings FW. Veterinary Parasitology. 2nd ed. Oxford: Blackwell Science (1996).

17. Soulsby EJL. Helminths, Arthropods and Protozoa of Domesticated Animals. 7th ed. London: Baillière Tindall (1982).

18. Dunn AM. Veterinary Helminthology. 2nd ed. London: William Heinemann Medical Book Ltd (1978).

19. Geoffrey L. Veterinary Helminthology and Entomology. 5th ed. Edinburg, TX: Oliver and Boyd (1962).

20. Campbell MJ. Statistics at Square Two. 2nd ed. Blackwell: BMJ Books (2006).

21. Cériac S, Durbant P, Godard X, Barbier C, Feuillet D, Félicité $\mathrm{Y}$, et al. Effect of the nutritional status of Creole goats on the density-dependent prolificacy of Haemonchus contortus. Vet Parasitol. (2019) 276:108973. doi: 10.1016/j.vetpar.2019.10 8973

22. Bambou JC, Ceï W, Arquet R, Calif V, Bocage B, Mandonnet N, et al. Mixed grazing and dietary supplementation improve the response to gastrointestinal nematode parasitism and production performances of goats. Front Vet Sci. (2012) 8:628686. doi: 10.3389/fvets.2021.6 28686

23. Hoste H, Torres-Acosta JFJ, Quijada J, Chan-Perez I, Dakheel MM, Kommuru DS, et al. Interactions between nutrition and infections with Haemonchus contortus and related gastrointestinal nematodes in small ruminants. In: Gasser RB, VonSamsonHimmelstjerna G, editors. Haemonchus contortus and Haemonchosis - Past, Present and Future Trends, London: Academic Press, (2016). 111:239-351.

24. Ghosh CP, Datta S, Mandal D, Das AK, Roy DC, Roy A, et al. Body condition scoring in goat: impact and significance. J Entomol Zool Stud. (2019) 7:554-60.

25. Das M, Laha R, Goswami A, Goswami A. Gastrointestinal parasitism of goats in hilly region of Meghalaya, India. Vet World. (2017) 10:81. doi: 10.14202/vetworld.2017.81-85 
26. Chikweto A, Tiwari K, Bhaiyat MI, Carloni J, Pashaian K, Pashaian A, et al. Gastrointestinal parasites in small ruminants from Grenada, West Indies: a coprological survey and a review of necropsy cases. Vet Parasitol Reg Stud Rep. (2018) 13:130-4. doi: 10.1016/j.vprsr.2018.05.004

27. Kaur S, Singla LD, Sandhu BS, Bal MS, Kaur P. Coccidiosis in goats: pathological observations on intestinal developmental stages and anticoccidial efficacy of amprolim. Indian J Anim Res. (2019) 53:245-9. doi: 10.18805/ijar.B-3471

28. Taylor M, Coop R, Wall R. Veterinary Parasitology. 3rd ed. Oxford: Blackwell Publishing (2007).

29. Idika IK, Iheagwam CN, Ezemonye CN, Nwosu CO. Gastrointestinal nematodes and body condition scores of goats slaughtered in Nsukka, Nigeria. Niger Vet J. (2012) 33:440-7.

30. Bowman D. Georgis' Parasitology for Veterinarians. 10th ed. St. Louis, MO: Elsevier (2014).

31. Paul BT, Biu AA, Ahmed GM, Mohammed A, Philip MH, Jairus Y. Point prevalence and intensity of gastrointestinal parasite ova/oocyst and its association with Body Condition Score (BCS) of sheep and goats in Maiduguri, Nigeria. J Adv Vet Parasitol. (2016) 3:81-8. doi: 10.14737/journal.jap/2016/3.3.81.88

32. Zvinorova PI, Halimani TE, Muchadeyi FC, Matika O, Riggio V, Dzama K. Prevalence and risk factors of gastrointestinal parasitic infections in goats in low-input low-output farming systems in Zimbabwe. Small Rumin Res. (2016) 143:75-83. doi: 10.1016/j.smallrumres.2016.09.005

33. Sánchez CA, Becker DJ, Teitelbaum CS, Barriga P, Brown LM, Majewska $\mathrm{AA}$, et al. On the relationship between body condition and parasite infection in wildlife: a review and meta-analysis. Ecol Lett. (2018) 21:1869-84. doi: $10.1111 /$ ele. 13160

34. Moore J. Parasites and the Behavior of Animals. Oxford: Oxford University Press (2002).

35. Graham AL, Shuker DM, Pollitt LC, Auld SK, Wilson AJ, Little TJ. Fitness consequences of immune responses: strengthening the empirical framework for ecoimmunology. Funct Ecol. (2011) 25:5-17. doi: 10.1111/j.1365-2435.2010.01777.x

36. Rynkiewicz EC, Pedersen AB, Fenton A. An ecosystem approach to understanding and managing within-host parasite community dynamics. Trends Parasitol. (2015) 31:212-21. doi: 10.1016/j.pt.2015.02.005

37. Wang CR, Xiao JY, Chen AH, Chen J, Wang Y, Gao JF, et al. Prevalence of coccidial infection in sheep and goats in northeastern China. Vet Parasitol. (2010) 174:213-7. doi: 10.1016/j.vetpar.2010.08.026

38. Koudela B, Boková A. Coccidiosis in goats in Czech Republic. Vet Parasitol. (1998) 76:261-7. doi: 10.1016/S0304-4017(97)00147-7

39. Silva LMR, Carrau T, Vila-Viçosa MJM, Musella V, Rinaldi L, Failing K, et al. Analysis of potential risk factors of caprine coccidiosis. Vet Parasitol Reg Stud Rep. (2020) 22:100458. doi: 10.1016/j.vprsr.2020.100458

40. Vasilková Z, Krupicer I, Legáth J, Kovalkovicova N, Petko B. Coccidiosis of small ruminants in various regions of Slovakia. Acta Parasitol. (2004) 49:2725.

41. Szefer P, Nriagu JO. Mineral Components in Foods, Chemical and Functional Properties of Food Components Series. Boca Raton, FL: CRC Press; Tylor and Francis Group (2007). p. 163-95.

42. Wang CR, Qiu JH, Zhu XQ, Han XH, Ni HB, Zhao JP, et al. Survey of helminths in adult sheep in Heilongjiang Province, People's Republic of China. Vet Parasitol. (2006) 140:378-82. doi: 10.1016/j.vetpar.2006.04.008

43. Umur S, Yukari BA. Seasonal activity of gastro-intestinal nematodes in goats in Burdur region, Turkey. Turk J Vet Anim Sci. (2005) 29:441-8.

44. Babják M, Königová A, Urda-Dolinská M, Várady M. Gastrointestinal helminth infections of dairy goats in Slovakia. Helminthologia. (2017) 54:2117. doi: 10.1515/helm-2017-0027

45. Ghimire TR, Bhattarai N. A survey of gastrointestinal parasites of goats in a goat market in Kathmandu, Nepal. J Parasit Dis. (2019) 43:686-95. doi: 10.1007/s12639-019-01148-w

46. Di Cerbo AR, Manfredi MT, Zanzani S, Stradiotto K. Gastrointestinal infection in goat farms in Lombardy (Northern Italy): analysis on community and spatial distribution of parasites. Small Rumin Res. (2010) 88:102-12. doi: 10.1016/j.smallrumres.2009.12.017
47. Rabbi AKMA, Islam A, Anisuzzaman M, Majumder S, Rahman MH. Does feeding system influence parasitism in Black Bengal Goats in Bangladesh? Progress Agric. (2011) 22:85-95. doi: 10.3329/pa.v22i1-2.16470

48. Jittapalapong S, Saengow S, Pinyopanuwat N, Chimnoi W, Khachaeram W, Stich RW. Gastrointestinal helminthic and protozoal infections of goats in Satun, Thailand. J Trop Med Parasitol. (2012) 35:48-54.

49. Odermatt P, Lv S, Sayasone S. Less common parasitic infections in Southeast Asia that can produce outbreaks. Adv Parasitol. (2010) 72:409-35. doi: 10.1016/S0065-308X(10)72013-3

50. Dagnachew S, Amamute A, Temesgen W. Epidemiology of gastrointestinal helminthiasis of small ruminants in selected sites of North Gondar zone, Northwest Ethiopia. Ethiop Vet J. (2011) 15:57-68. doi: 10.4314 /evj.v15i2.67694

51. Attindehou S, Salifou S. Epidemiology of cestodes infections in sheep and goats in Benin. Vet Res. (2012) 5:59-62.

52. Kumsa B, Tadese T, Sori T, Duguma R, Hussen B. Helminths of sheep and goats in central Oromia (Ethiopia) during the dry season. J Anim Vet Adv. (2011) 10:1845-9. doi: 10.3923/javaa.2011.1845.1849

53. Sharma DK, Paul S, Gururaj K. Gastrointestinal helminthic challenges in sheep and goats in afro-asian region: a review. Anim Res. (2020) 10:1-18. doi: 10.30954/2277-940X.01.2020.1

54. Scala A, Tamponi C, Dessì G, Sedda G, Sanna G, Carta S, et al. Dicrocoeliosis in extensive sheep farms: a survey. Parasit Vect. (2019) 12:1-7. doi: 10.1186/s13071-019-3609-2

55. Khanjari A, Bahonar A, Fallah S, Bagheri M, Alizadeh A, Fallah M, et al. Prevalence of fasciolosis and dicrocoeliosis in slaughtered sheep and goats in Amol Abattoir, Mazandaran, northern Iran. Asian Pac J Trop Dis. (2014) 4:120-4. doi: 10.1016/S2222-1808(14)60327-3

56. Godara R, Katoch R, Yadav A, Borah MK. Dicrocoeliosis in goats in Jammu, India. J Parasit Dis. (2014) 38:201-4. doi: 10.1007/s12639-012-0212-2

57. Karki K, Bashir BK, Subedi JR. A case study on seasonal prevalence of helminth parasites in goats (Capra hircus) in Kalanki (Khasibazzar), Kathmandu Nepal. Bull Env Pharmacol Life Sci. (2012) 1:11-13.

58. Tan TK, Chandrawathani P, Low VL, Premaalatha B, Lee SC, Chua KH, et al. Occurrence of gastro-intestinal parasites among small ruminants in Malaysia: highlighting Dicrocoelium infection in goats. Trop Biomed. (2017) 34:963-9.

59. Usman AM, Malann YD, Babeker EA. Prevalence of Gastrointestinal parasitic infections among ruminants animals slaughtered in Katagum abattoir of Bauchi state, Nigeria. Int J Innov Res Adv Stud. (2016) 3:167-70.

60. Berrag B, Urquhart GM. Epidemiological aspects of lungworm infections of goats in Morocco. Vet Parasitol. (1996) 61:81-95. doi: 10.1016/0304-4017(95)00803-9

61. Adem J. Lung Worm Infection of Small Ruminant in Ethiopia. Worm infection of small ruminant in Ethiopia. Adv Life Sci Technol. (2016) 43:12-22.

62. Paran MS, Dey AR, Begum N, Hossain MS, Alam M. Prevalence of pulmonary parasitic infection in goats of Mymensingh. BJVAS. (2015) 3:1-6.

63. Chakraborty S, Kumar A, Tiwari R, Rahal A, Malik Y, Dhama K, et al. Advances in diagnosis of respiratory diseases of small ruminants. Vet Med Int. (2014) p. 16. doi: 10.1155/2014/508304

64. Borji H, Azizzadeh M, Ebrahimi M, Asadpour M. Study on small ruminant lungworms and associated risk factors in northeastern Iran. Asian Pac J Trop Med. (2012) 5:853-6. doi: 10.1016/S1995-7645(12)60159-X

65. Kebede S, Menkir S, Desta M. On farm and Abattoir study of Lungworm infection of small ruminants in selected areas of Dale District, Southern Ethiopia. Int J Curr Microbiol App Sci. (2014) 3:1139-52.

66. Can E, Vieira A, Battini M, Mattiello S, Stilwell G. On-farm welfare assessment of dairy goat farms using animal-based indicators: the example of 30 commercial farms in Portugal. Acta Agric Scand A Anim Sci. (2016) 66:43-55. doi: 10.1080/09064702.2016.1208267

67. Battini M, Peric T, Ajuda I, Vieira A, Grosso L, Barbieri S, et al. Hair coat condition: a valid and reliable indicator for on-farm welfare assessment in adult dairy goats. Small Rumin Res. (2015) 123:197-203. doi: 10.1016/j.smallrumres.2014.12.009

68. Veit HP, McCarthy F, Friedericks J, Cashin M, Angert R. A surveyof goat, and cattle diseases in the Artibonite Valley, Haiti, West Indies. Rev Elev Med Vet Pays Trop. (1993) 46:27-38. doi: 10.19182/remvt.9377 
69. Waller PJ. Sustainable nematode parasite control strategies for ruminant livestock by grazing management and biological control. Anim Feed Sci Technol. (2006) 126:277-89. doi: 10.1016/j.anifeedsci.2005.08.007

70. Baumgard LH, Rhoads RP. Efects of heat stress on postabsorptive metabolism and energetics. Ann Rev Anim Biosci. (2013) 1:311-37. doi: 10.1146/annurev-animal-031412-103644

71. Salama AAK, Caja G, Hamzaoui S, Such X, Albanell E, Badaoui B, et al. Thermal stress in ruminants: responses and strategies for alleviation. In: Villalba JJ, Manteca X, editors. Animal Welfare in Extensive Production Systems. 1st ed. Shefeld: 5m Publishing (2016) 11-36.

72. NRC. Nutrient Requirements of Small Ruminants, Sheep, Goats, Cervids, and NewWorld camelids. Washington, DC: National Academy Press (2007).

73. Coloma-García W, Mehaba N, Llonch P, Caja G, Such X, Salama AAK. Prenatal heat stress effects on gestation and postnatal behavior in kid goats. PLoS ONE. (2020) 15:e0220221. doi: 10.1371/journal.pone.0220221

74. De Rosa G, Grasso F, Pacelli C, Napolitano F, Winckler C. The welfare of dairy buffalo. Ital J Anim Sci. (2009) 8:103-16. doi: 10.4081/ijas.2009.s1.103

75. Bøe KE, Andersen IL, Buisson L, Simensen E, Jeksrud WK. Flooring preferences in dairy goats at moderate and low ambient temperature. Appl Anim Behav Sci. (2007) 108:45-57. doi: 10.1016/j.applanim.2006.12.002

76. Winter AC. Lameness in sheep. Small Rumin Res. (2008) 76:149-53. doi: 10.1016/j.smallrumres.2007.12.008

77. Anzuino K, Bell NJ, Bazeley KJ, Nicol CJ. Assessment of welfare on 24 commercial UK dairy goat farms based on direct observations. Vet Rec. (2010) 167:774-80. doi: 10.1136/vr.c5892

78. Muri K, Stubsjøen SM, Valle PS. Development and testing of an on-farm welfare assessment protocol for dairy goats. Anim Welf. (2013) 22:385-400. doi: 10.7120/09627286.22.3.385

79. Fitzpatrick J, Scott M, Nolan A. Assessment of pain and welfare in sheep. Small Rum Res. (2006) 62:55-61. doi: 10.1016/j.smallrumres.2005.07.028

80. Smith MC, Sherman DM. Goat Medicine. Ames, IA: Wiley-Blackwell (2009).

81. Williamson LH. Caseous lymphadenitis in small ruminants. Vet Clin North Am Small Anim Pract. (2001) 17:359-71. doi: 10.1016/S0749-0720(15)30033-5

82. Mattiello S, Battini M, Mantova E, Noè L, Grosso L, Barbieri S. Evidence of poor welfare in goats with external abscesses. A preliminary study. Large Anim Rev. (2018) 24:113-8.
83. Klaas IC, Enevoldsen C, Vaarst M, Houe H. Systematic clinical examinations for identification of latent udder health types in Danish dairy herds. J Dairy Sci. (2004) 87:1217-28. doi: 10.3168/jds.S0022-0302(04)73272-5

84. Hemsworth PH. Human-animal interactions in livestock production. Appl Anim Behav Sci. (2003) 81:185-98. doi: 10.1016/S0168-1591(02)0 0280-0

85. Nenadović K, Karać P, Vučinić M, Teodorović R, Živanov D, Trailović R, et al. Assessment of the Welfare of Extensively Managed Autochtonous Sheep Breed Vlasicka Zackel using Animal-Based Measurements. Acta Vet Belgrade. (2020) 70:207-18. doi: 10.2478/acve-2020-0015

86. Jackson KM, Hackett D. A note: the effects of human handling on heart girth, behaviour and milk quality in dairy goats. Appl Anim Behav Sci. (2007) 108:332-6. doi: 10.1016/j.applanim.2007.01.011

87. Mattiello S, Battini M, Andreoli E, Minero M, Barbieri S, Canali E. Avoidance distance test in goats: A comparison with its application in cows. Small Rum Res. (2010) 91:215-8. doi: 10.1016/j.smallrumres.2010. 03.002

Conflict of Interest: The authors declare that the research was conducted in the absence of any commercial or financial relationships that could be construed as a potential conflict of interest.

Publisher's Note: All claims expressed in this article are solely those of the authors and do not necessarily represent those of their affiliated organizations, or those of the publisher, the editors and the reviewers. Any product that may be evaluated in this article, or claim that may be made by its manufacturer, is not guaranteed or endorsed by the publisher.

Copyright (c) 2021 Nenadović, Ilić, Jovanović, Bugarski and Vučinić. This is an open-access article distributed under the terms of the Creative Commons Attribution License (CC BY). The use, distribution or reproduction in other forums is permitted, provided the original author(s) and the copyright owner(s) are credited and that the original publication in this journal is cited, in accordance with accepted academic practice. No use, distribution or reproduction is permitted which does not comply with these terms. 